\title{
Control of Gingival Inflammation in a Teenager Population Using Ultrasonic Prophylaxis
}

\author{
Arthur Belém NOVAES JÚNIOR \\ Sérgio Luís Scombatti de SOUZA \\ Mário TABA Jr. \\ Marcio Fernando de Moraes GRISI \\ Luciane Cristina SUZIGAN \\ Roberta Santos TUNES
}

\begin{abstract}
Department of Bucco-Maxillo-Facial Surgery and Traumatology and Periodontology, Faculty of Dentistry of Ribeirão Preto, University of São Paulo, Ribeirão Preto, SP, Brazil
\end{abstract}

\begin{abstract}
Gingival inflammation is clinically characterized by gingival redness, swelling and increased tendency of bleeding of the soft tissue. Bacterial biofilm is the etiological agent. If, at this stage, the bacterial biofilm is removed and appropriate control methods are applied, remission of gingival inflammation occurs. This study evaluated the effectiveness of a single session of ultrasonic prophylaxis for the reduction of gingivitis in an adolescent population using the Plaque Index (PI) and Gingival Index (GI). The study sample consisted of 15 male adolescent students selected at a dentist's office of a public high school. Prior to treatment (baseline), plaque index (PI) and bleeding on probing (BOP) were recorded. The patients then received oral hygiene instructions and ultrasonic prophylaxis. Follow-up exams were made 15 and 30 days after the ultrasonic prophylaxis, again recording PI and BOP. The data were analyzed by the Student's t-test for dependent samples. Correlation analysis between presence of biofilm and bleeding on probing was also made using the Pearson correlation test. There was a statistically significant decrease in the plaque index and bleeding on probing between baseline and examinations at both 15 days and 30 days $(\mathrm{p}<0.05)$. However, the difference between the means at 15 and 30 days was statistically similar. The correlation analysis showed correlation between both parameters $(\mathrm{p}<0.05)$. The results indicate that a single session of ultrasonic prophylaxis associated to oral hygiene instructions is efficient to reverse gingivitis in adolescents.
\end{abstract}

Key Words: gingivitis, plaque control, ultrasonic scaling.

\section{INTRODUCTION}

Gingivitis is clinically characterized by inflammation of the marginal gingiva without detectable loss of bone or connective tissue attachment. The marginal gingiva appear red (erythema), swollen (edematous) and will bleed easily upon probing. Histologically, this inflammatory disease is characterized by an ulceration of the sulcul epithelium and an inflammatory cell infiltration of the underlying connective tissue. The epithelial attachment remains at the cemento-enamel junction (CEJ), and upon removal of the bacterial plaque, the disease process is reversed and complete remission occurs. Chronic gingivitis differs significantly from periodontitis since in the latter condition, pathological changes are largely irreversible (1).
Gingivitis is the most common and prevalent form of periodontal diseases among children and adolescents. Its incidence and severity increase from childhood to adolescence, reaching a peak prevalence of $80 \%$ at 11-13 years of age (1). Starting at an early age, gingivitis increases in severity and peaks at the onset of puberty. Thereafter, as the severity of gingivitis decreases, chronic periodontitis measured by loss of attachment becomes dominant and continues to increase in severity with age (2). Addy et al. (3) reported that dental plaque and gingivitis scores, associated with mean depth of gingival sulcus, decreased markedly between the ages of 11-12 and 15-16, perhaps reflecting a decrease in false pocketing and gingival edema associated with puberty and tooth eruption. On the other hand, there was an increase in the mean depth of 
the gingival sulcus at the ages of 19-20 years, possibly beginning the initiation of periodontal breakdown and the appearance of periodontal pockets.

In spite of the fact that gingivitis is a precursor of periodontal disease, only about $7-15 \%$ of the adult population will go on to develop periodontitis with severe periodontal destruction (4). Since the pathogenesis of this chronic disease is complex, without knowing how to differentiate stable gingivitis from progressive gingivitis or the moment at which progressive gingivitis will turn into destructive periodontal disease, early diagnosis, treatment and prevention of this initial inflammatory pathology by the general dentist is of critical importance for public health, reducing the prevalence and severity of chronic periodontitis in adulthood $(1,2,4,5)$.

Several statistical investigations have shown a close relationship between the incidence of gingivitis and oral hygiene $(1-4,6,7)$. The inflammatory changes in the marginal gingiva are due to the accumulation of periodontopathogenic bacteria on the tooth surface. The majority of individuals develop gingivitis clinically after 10 to 21 days of continued bacterial biofilm growth. If, at this stage, the bacterial biofilm is removed and appropriate plaque control methods are applied, remission of gingival inflammation occurs $(1,7)$. Therefore, in both children and adolescents, the control of supragingival plaque by personal oral hygiene or programs of prevention and professional scaling are effective in improving the periodontal condition of the population, especially in developing countries, as part of a program of public health $(2,3,6,8)$. This fact was observed by Lövdal et al. (9) who evaluated the combined effect of subgingival scaling at 6-month intervals associated with controlled oral hygiene over a period of five years in a group originally comprising 1428 men and women. They concluded that this combined therapy effectively reduces the incidence of gingivitis and tooth loss.

Lembariti et al. (8), analyzing the effect of a single scaling (with and without oral hygiene instruction $[\mathrm{OHI}]$ ) on gingival bleeding and calculus formation in 136 students of both sexes (aged 14-18 years) for 22 months, verified that scaling resulted in a $20 \%$ reduction of the gingival bleeding score, a result that remained during the entire period of study. $\mathrm{OHI}$ had no significant effect on the calculus and bleeding scores. Follow-up examinations on gingival bleeding and cal- culus were carried out 6,12 and 22 months after the scaling session. Since the effect of scaling alone on the gingival condition was small and the effect of a single OHI negligible, the practice of occasional scaling without repeated OHI should be considered of little use in improving periodontal health.

Another aspect that is important to be considered is the type of instrument that can be applied to improve the supra- and subgingival scaling and root planing. Several studies have evaluated the effects of hand and ultrasonic instrumentation on root surface topography and subgingival plaque and calculus removal, revealing that, although only partially effective in removing subgingival calculus, both methods of instrumentation appear to be effective for bacterial removal from subgingival root surfaces $(10,11)$. After observation with scanning electron microscopy (SEM) of the tooth surfaces treated with both methods, the authors verified that at low magnification, the ultrasonic method produced greater disturbed root surface topography than hand instrumentation. However, at higher magnification, both methods produce similar surface topography (11). Checchi and Pelliccioni (12) reported that both treatments, either with ultrasonic scalers or curettes, caused the roots to lose their toxicity, as there was no significant difference in fibroblast growth between the root surfaces treated by both methods.

In relation to the clinical efficiency of these treatment methods, Copulos et al. (13), investigating whether an ultrasonic scaler with a modified tip is as effective as Gracey curettes in providing supportive periodontal treatment for patients, showed that both treatments were equally effective for all clinical parameters measured and also in reducing the elastase levels, and reducing the microbial environment, with less time needed for the ultrasonic method to complete an effective debridement. Besides, Croft (14) suggested that the modified ultrasonic tips were the best instruments for scaling and root planning, because this technique was 1) easiest to learn, 2) easiest to teach, 3) most efficient in removing subgingival irritants, 4) least damaging to the root, 5) most effective in approaching the bottom of the pocket, and 6) least fatiguing for the operator.

Therefore, the purpose of this study was to verify the effectiveness of a single session of ultrasonic prophylaxis in the reduction of gingivitis in an adolescent population, evaluating if this method can be a faster and 
easier way to prevent periodontal diseases in this population, and thus be used as part of public health preventive programs.

\section{MATERIAL AND METHODS}

\section{Study Population}

The study sample consisted of 15 adolescent students selected at a dentist office of a public high school. The subjects were selected according to the following criteria: 1) male; 2) non-smoker; 3) 14-19 years old; 4) presence of gingival inflammation without true periodontal pockets or bone loss. The exclusion criteria were: 1) female (to exclude any possible hormonal influence on the clinical condition); 2) history of systemic disease or requirement of antibiotic prophylaxis that might affect the outcome of the study; 3 ) use of antibiotics in the last 6 months; 4) smokers (to exclude the smoke influence on the inflammatory clinical parameters such bleeding on probing). Each subject received oral and written explanations of the study, and signed a consent form.

\section{Clinical Procedures}

Prior to treatment, a baseline clinical exam was made in which the following clinical parameters were recorded: 1) Plaque Index (PI) (15), using disclosing wafers that stain the tooth surfaces covered by bacterial biofilm, assessing the percentage of plaque surfaces; 2 ) bleeding on probing (BOP), obtained through observation of bleeding after probing 6 sites of each tooth (mesio-buccal, buccal, disto-buccal, mesio-lingual, lingual, disto-lingual). A periodontal probe with Williams calibration was used (Hu-Friedy Co., Chicago, IL).

After examination, the patients received oral hygiene instructions $(\mathrm{OHI})$, which consisted of the

Table 1. Plaque index at the different time periods.

\begin{tabular}{lrcrr}
\hline & \multicolumn{4}{c}{ Plaque index } \\
\cline { 2 - 5 } & Minimal & Maximum & Mean & SD \\
\hline Baseline & 46.4 & 96.3 & 77.7 & 14.1 \\
15 days after treatment & 31.2 & 59.5 & 44.3 & 7.7 \\
30 days after treatment & 7.1 & 68.1 & 36.3 & 18.5 \\
\hline
\end{tabular}

Bass Modified brushing technique (17) and flossing techniques.

All study procedures were carried out by one examiner (L.C.S.), previously calibrated, in order to avoid index application or interpretation error.

One week after receiving the oral hygiene instructions, the patients received a single ultrasonic (ENAC, Osada, Japan) prophylaxis session, in which supra- and subgingival biofilm and calculus were removed.

The parameters were recorded again in 2 followup examinations 15 and 30 days after treatment. In both sessions, oral hygiene instructions were reinforced to the patients.

\section{Statistical Analysis}

The collected data were statistically analyzed to verify significant differences between clinical parameters recorded at baseline and 15 and 30 days after treatment. The effect of treatment (between baseline and 15 and 30 days post-treatment) and the potential of oral hygiene instructions to maintain gingival health (between days 15 and 30) were analyzed by the Student's t-test for dependent samples. A correlation analysis between presence of biofilm and bleeding on probing was also made using the Pearson correlation test. The $5 \%$ level of probability was considered statistically significant.

\section{RESULTS}

In this study, 1572 dental surfaces from 15 patients were analyzed. Among these, 1222 surfaces (77.7\%) were covered by biofilm previous to treatment and oral hygiene instruction. Gingival bleeding was scored in 867 sites $(55.1 \%)$.

The plaque index decreased consistently from

Table 2. Bleeding on probing index at the different time periods.

\begin{tabular}{lcccc}
\hline & \multicolumn{4}{c}{ Bleeding on probing index } \\
\cline { 2 - 5 } & Minimum & Maximum & Mean & SD \\
\hline Baseline & 33.0 & 81.0 & 55.1 & 16.5 \\
15 days after treatment & 17.0 & 41.0 & 27.7 & 23.4 \\
30 days after treatment & 0.9 & 43.1 & 16.2 & 11.7 \\
\hline
\end{tabular}


baseline to 15 and 30 days $(77.7,44.3$ and 36.3, respectively). This decrease in plaque index was verified in all patients from baseline to 15 days, but 3 patients presented a slight increase in this index from 15 to 30 days (Table 1).

There was a significant decrease in bleeding on probing (BOP) from baseline to 15 and 30 days (55.1, 27.7 and 16.2, respectively). This decrease in BOP was verified in all patients from the first exam to 15 days after treatment, but again 3 patients presented a slight increase in this index from 15 days to 30 days after treatment (Table 2).

The results were compared statistically by the Student's t-test for dependent samples, in order to verify if there were significant differences between the means of both parameters in each exam. There was a statistically significant difference between the means of the plaque index obtained at baseline and after 15 days (33.4\%). Similarly, there was a statistically significant difference between the means obtained in baseline and after 30 days (41.4\%). For both situations, the $\mathrm{p}$ value was 0.000 . However, the difference between the means of the exams at 15 and 30 days (8.0\%) was not statistically significant $(\mathrm{p}=0.071)$.

There was a statistically significant difference between the means of bleeding on probing obtained at baseline and after 15 days (33.2\%). Similarly, there was a statistically significant difference between the means at baseline and after 30 days (38.9\%). For both situations, the $\mathrm{p}$ value was 0.000 . However, the difference between the means at 15 and 30 days $(5.6 \%)$ was not statistically significant $(\mathrm{p}=0.101)$.

\section{DISCUSSION}

Since plaque-induced chronic gingivitis is the most common periodontal condition found in young children and adolescents, early diagnosis, treatment and prevention must be carried out in order to prevent more severe periodontal diseases in adults. Gingivitis is a reversible disease and therapy must be aimed primarily at the reduction of etiologic factors (oral bacteria and associated calcified and noncalcified deposits) to reduce or eliminate inflammation, thereby allowing gingival tissues to heal (17-19).

The results of this study have demonstrated that a single session of ultrasonic prophylaxis associated with oral hygiene instructions is efficient for the reduc- tion of the gingival inflammation in a group of adolescents during a period of 30 days. Lövdal et al. (9) also concluded that the combined effect of subgingival scaling and controlled oral hygiene over a period of 5 years resulted in an average reduction of the incidence of gingivitis to one-eighth in individuals who started with a "good" oral hygiene, to one-third in those starting with a "fairly good" oral hygiene and to one-half in those who started with a "not good" oral hygiene.

The fact that there was a statistically significant difference between the means of plaque index and bleeding on probing obtained at baseline and after 15 days and after 30 days, and no significant difference between 15 and 30 days indicates that after a single treatment, the inflammatory condition recedes and the maintenance of gingival health can be established, through periodontal supportive therapy.

The results of this study only demonstrated that it is possible to reverse gingivitis by a simple and inexpensive intervention that could be part of a public health program. However, in order to provide longterm inhibition of gingivitis, clinical trials indicate that self-administered plaque control programs must be associated with periodic professional reinforcement $(6,18)$. This was confirmed by Lembariti et al. (8) who analyzed the effect of a single scaling with and without oral hygiene instruction on gingival bleeding and calculus formation in adolescent students for 22 months. The authors observed that scaling resulted in a $20 \%$ reduction of the gingival bleeding score, which remained throughout the study period, and $\mathrm{OHI}$ had no significant effect on the calculus and bleeding scores, concluding that the practice of occasional scaling without repeated $\mathrm{OHI}$ should be considered of little use in improving the standard of periodontal health. Thus, according to the fact that to improve periodontal health and promote long-term inhibition of gingivitis, it is necessary to associate self-administered plaque control programs with periodic professional reinforcement.

The present study did not have a control group because it's objective was to show how a single ultrasonic prophylaxis can reverse gingivitis in a short period of time, being only a part of professional reinforcement in public health programs.

A correlation analysis, made by the Pearson method of linear correlation, between the presence of plaque and bleeding resulted in a level of $1 \%$, indicating that as the plaque index decreased, gingival bleed- 
ing also decreased directly proportional. Therefore, a direct relationship between biofilm accumulation and gingival inflammatory condition was established (1). This is in agreement with other studies that have established that accumulation of plaque is essential for the initiation of gingivitis, and that bacterial quality and host resistance are important factors in the development of periodontitis (7).

The present results also indicated that the ultrasonic scalers are efficient in reducing bleeding upon probing as well as the subgingival microflora, also provided by the constant flushing activity during instrumentation, disrupting bacterial cell walls (20). Finally, the results of this study confirmed that a single session of ultrasonic prophylaxis associated to oral hygiene instructions is a fast and inexpensive method of reversing gingivitis in adolescents. It can be suggested that this method should be applied to this population as part of a public health program in order to prevent more severe periodontal diseases.

\section{RESUMO}

A gengivite é clinicamente caracterizada por vermelhidão, edema e tendência aumentada de sangramento do tecido gengival. $\mathrm{O}$ biofilme bacteriano é o seu agente etiológico. Se, neste estágio, o biofilme bacteriano for removido e métodos de controle apropriados forem instituídos, ocorre remissão total da inflamação da gengiva. Este estudo avaliou, através da análise dos índices de placa (IP) e gengival (IG), a efetividade de uma única sessão de profilaxia com ultra-som para a redução da gengivite em adolescentes. A amostra consistiu de 15 adolescentes do sexo masculino selecionados no consultório dentário de uma escola publica de segundo grau. Previamente ao tratamento (exame inicial), foram anotados o índice de placa (IP) e o sangramento à sondagem (IG). Os pacientes receberam então instruções de higiene oral e profilaxia com ultra-som. Foram realizados novos exames 15 e 30 dias após a profilaxia com ultra-som, novamente anotando IP e IG. Os dados foram analisados através do teste $t$ de Student para amostras dependentes. Foi feita também a análise de correlação entre a presença de biofilme e sangramento à sondagem, através do teste de correlação de Pearson. Houve uma diminuição estatisticamente significante nos índices de placa e sangramento à sondagem entre o exame inicial e os exames de 15 e 30 dias $(\mathrm{p}<0,05)$. Entretanto, a diferença das médias entre os exames de 15 e 30 dias foi estatisticamente não significante. A análise de correlação mostrou haver correlação entre os dois parâmetros $(\mathrm{p}<0,05)$. Os resultados indicaram que uma única sessão de profilaxia com ultra-som, associada a instruções de higiene oral, é eficiente na reversão de quadro de gengivite em adolescentes.

\section{REFERENCES}

1. Dibart S. Children, adolescents and periodontal diseases. J Dent 1997:25:79-89.

2. Spencer AJ, Beighton D, Higgins T. Periodontal disease in five and six year old children. J Periodontol 1983;54:19-22.

3. Addy M, Hunter ML, Kingdon A, Dummer PM, Shaw WC. An 8year study of changes in oral hygiene and periodontal health during adolescence. Int J Paediat Dent 1994;4:75-80.

4. Kallio P, Nordblad A, Croucher R, Ainamo J. Self-reported gingivitis and bleeding gums among adolescents in Helsinki. Community Dent Oral Epidemiol 1994;22:277-282.

5. Pilot T, Barmes DE, Leclercq MH, McCombie BJ, Sardo Infirri J. Periodontal conditions in adults, 35-44 years of age: an overview of CPITN data in the WHO Global Oral Data Bank. Community Dent Oral Epidemiol 1986;14:310-312.

6. Rayner JA. A dental health education programme, including home visits, for nursery school children. Br Dent J 1992;172:5762.

7. Van Der Weijden GA, Timmerman MF, Danser MM, Nijboer A, Saxton CA, Van der Velden U. Effect of pre-experimental maintenance care duration on the development of gingivitis in a partial mouth experimental gingivitis model. J Periodent Res 1994;29:168-173.

8. Lembariti BS, Van Der Weijden GA, Van Palenstein Helderman WH. The effect of a single scaling with or without oral hygiene instruction on gingival bleeding and calculus formation. J Clin Periodontol 1998;25:30-33.

9. Lövdal A, Arno A, Schei O, Waerhaug J. Combined effect of subgingival scaling and controlled oral higiene on the incidence of gingivitis. Acta Odont Scand 1961;19:537-555

10. Breininger DR, O'Leary TJ, Blumenshine RVH. Comparative effectiveness of ultrasonic and hand scaling for the removal of subgingival plaque and calculus. J Periodontol 1987;58:9-18.

11. Garnick JJ, Dent J. A scanning electron micrographical study of root surfaces and subgingival bacteria after hand and ultrasonic instrumentation. J Periodontol 1989;60:441-447.

12. Checchi L, Pelliccioni GA. Hand versus ultrasonic instrumentation in the removal of endotoxins from root surfaces in vitro. J Periodontol 1988;59:398-402.

13. Copulos TA, Low SB, Walker CB, Trebilcock YY, Hefti AF. Comparative analysis between a modified ultrasonic tip and hand instruments on clinical parameters of periodontal disease. J Periodontol 1993;64:694-670.

14. Croft LK. Ultrasonics in periodontal therapy - The paradigm has changed. Texas Dent J 1995;112:7-12.

15. O'Leary TJ, Drake RB, Naylor JE. The plaque control record. J Periodontol 1972;43:38-42.

16. Bass CC. An effective method of personal oral hygiene. J Lousiana Med Soc 1954;106:100-112.

17. Modéer T, Wondimu B. Periodontal diseases in children and adolescents. Dent Clin N Am 2000;44:633-659.

18. American Academy of Periodontology. Treatment of plaque-induced gingivitis, chronic periodontitis, and other clinical conditions. J Periodontol 2001;72:1790-1800.

19. Tae-Ju OH, Eber R, Wang H-L. Periodontal diseases in the child and adolescent. J Clin Periodontol 2002;29:400-410.

20. American Academy of Periodontology. Sonic and ultrasonic scalers in periodontics. J Periodontol 2000;71:1792-1801. 